\title{
APPLICATION OF HEART TECHNIQUE FOR HUMAN RELIABILITY ASSESSMENT - A SERBIAN EXPERIENCE
}

\author{
UDC331.468:621.311(497.11)
}

\author{
Evica Stojiljkovic $^{1}$, Bojan Bijelic ${ }^{2}$, Marko Cvetkovic ${ }^{3}$ \\ ${ }^{1,2}$ University of Niš, Faculty of Occupational Safety, Niš, Serbia \\ ${ }^{3}$ University of Porto, Faculty of Engineering, Department of Occupational Safety and Health, \\ Porto, Portugal
}

\begin{abstract}
In complex industrial systems, human error has been cited as a cause or a contributing factor in accidents and disasters. The need for improved Human Reliability Assessment (HRA) methodologies that should be applied in Probabilistic Safety Assessments, ever since the early 1990s, has motivated a number of major activities in research and development worldwide. Therefore, the main purpose of this paper is to show the practical application of Human Error Assessment and Reduction Technique (HEART) for HRA in Electric Power Company of Serbia (EPCS). The usefulness of this technique for HRA has been approved in a case study of an accident which occurred during a repair on a 10/0.4 kV steel lattice tower "Maricicice", Kuršumlija (jurisdiction of EPCS, ED "Jugoistok", Nis, Serbia). For the purpose of this study, a database on work-related injuries, accidents, and critical interventions that occurred over a 10-year period was created. The research comprised an analysis of 1074 workplaces, with a total of 3997 employees. The case study performed at the EPCS confirmed that the HEART is based on knowledge of human activities and relies on expert opinion to determine the Error Producing Condition (EPCs) that affected the situation. The HEART can be used in different industrial systems, as a risk assessment, accident investigation and design tool. In addition, it is a relatively fast tool for assessment of human error probability that is easily applied and understood.
\end{abstract}

Key words: Human Reliability Assessment, Human Error, Human Error Assessment and Reduction Technique, Error Producing Condition.

\section{INTRODUCTION}

Review of literature data regarding Human Reliability Assessment (HRA) shows that Human Errors (HEs) are one of the leading causes of accidents in complex systems [12; 20].

Received December 12, 2017 / Accepted January 10, 2018

Corresponding author: Evica Stojiljkovic

Faculty of Occupational Safety, Čarnojevića 10a, 18000 Niš, Serbia

E-mail: evica.stojiljkovic@znrfak.ni.ac.rs 
The analysis of human activities in different industrial processes requires a very demanding research procedures, conditioned by identification, modeling and quantification of Human Error Probability (HEP) [9; 11]. Therefore, a synergistic approach to this kind of research is needed, using psychological, ergonomic, engineering, mathematical and other related approaches.

The common term "Human Error" has been defined by Swain [25] as "a member of a set of human actions that exceeds some limit of acceptability, i.e. an out of tolerance action (or failure to act) where the limits of performance are defined by the system". Human error may be triggered by different factors: insufficient qualifications of an operator, lack of precision, cognitive failure or concentration deficiency, failure to understand and follow rules, etc. [10; 22]. Therefore, human errors are the result of person's performances, i.e. character. Performance depends on many different factors that are called Performance Shaping Factors (PSFs). Performance Shaping Factors can increase or decrease the HEP, depending on the individual characteristic of person, environment, work organization, task complexity and similar $[2 ; 21 ; 23 ; 24]$.

Human Error Analysis (HEA) is the most important part of assessment: if an important error is omitted, it will not be considered, and results can drastically underrate the human error in the analyzed system. Appropriate data, high quality information processing and correct connection of different databases are required for a proper HEA. Industrial accidents case studies are an ideal source of data regarding human errors; however, there are many issues complicating the gathering of this data. For this reason, methods based on the expert judgment are used for Human Error Assessment [more in: 19]. All methods for the quantification of human reliability (first, second and third generation) are based on calculation of HEP, as a measure of human reliability.

Among the first generation techniques are: Absolute Probability Judgement (APJ), Human Error Assessment and Reduction Technique (HEART), Justified Human Error Data Information (JHEDI), Probabilistic Human Reliability Analysis (PHRA), Operator Action Tree System (OATS), Success Likelihood Index Method (SLIM), etc. As it has been known, the first generation approaches to HRA tend to break a task into component parts and then consider the potential impact of modifying factors such as time pressure, equipment design and stress. Among these, the most popular and effective method used is Technique for Human Error Rate Prediction (THERP) [13; 14; 15; 16]. The base of THERP is event tree modelling, where each branch represents a combination of human activities, influences upon these activities, and results of these activities [9].

Some of the second-generation methods are as follows: A Technique for Human Error Analysis (ATHEANA), Cognitive Environmental Simulation (CES), Connectionism Assessment of Human Reliability (CAHR) and Méthode d'Evaluation de la Réalisation des Missions Opérateur pour la Sûreté (MERMOS). The majority of the proposed secondgeneration methods still do not have adequate experimental or theoretical bases for their key components. There is no fully implemented model of basic causal mechanisms that connect measurable PSFs or other characteristics of the context of oparator response. The problem extends to the side of quantification, with most of the suggested approaches still relying on implicit functions that relate PSFs to probabilities [17]. In a nutshell, some of the major drawbacks that influenced the development of new methods still remain unfulfilled. Firstgeneration methods have been generally verified whereas the second generation has yet to be empirically validated. The constraints and disadvantages of the second-generation HRA 
methods have influenced the improvement of existing methods. HRA experts used the shortcomings of the second-generation methods as the starting point in their new research.

The only method now defined as third generation is Nuclear Action Reliability Assessment (NARA) and is, in fact, an advanced version of HEART for the nuclear field. That is why a practical aplication of HEART technique will be presented in this paper.

HEART is a technique, derived from a wide range of findings in the ergonomics literature, which assumes that the probability of a human error may be modified according to the presence and strength of the identified Error Producing Conditions (EPCs). The method considers the human error as an isolated entity, unaffected by any other task [3;4]. The HEART assumes that any predicted reliability of task performance may be modified according to the presence of the identified EPCs. HEART requires a detailed analysis of a task to gather information about the EPCs that affect performance of the task operator. There are 38 EPC categories, and each is assigned a number by which unreliability might change engineering [27]. The nominal assignments are based on the research of human factor incidents conducted in several different industries. Unique probabilities can be created for the EPCs by using historical data gathered from past incidents caused by human error. However, the HEART method was not designed to provide human error probability calculations in real-time because the method relies on expert opinion to determine the EPCs that affected the situation. The HEART has been used by hazardous industries for 30 years as a risk assessment, accident investigation and design tool. It has given meaningful insight into human error in the nuclear industries [7], healthcare [5; 6], rail industries [8], aviation, process industries [18], and offshore engineering [1]. Therefore, the main purpose of this paper is to show the practical application of HEART for human errors analysis in Electric Power Company of Serbia (EPCS).

\section{METHODOLOGY}

Human Error Assessment and Reduction Technique are based on the knowledge of human activities (and generic task type), the EPCs and expert experience. The method can be divided in 6 procedural steps presented in Figure 1. Following are the procedural steps of the HEART method and their basic characteristics.

Identification of Human Error: Identification relates to guidelines for identification of type and source of human error for specific situation. These guidelines are enabling a qualitative insight of error type and can be used by an expert in case of error quantification.

Task Quantification: This step is important for deriving HEP since EPCs, basically, increase the nominal HEP when a general category is set, which serves as a limit beyond which human reliability cannot increase. Determining nominal human unreliability is done based on the classification of task type (complex task, routine tasks, etc.) [more in: 26; 27; $13 ; 19]$

Identification of Error Producing Condition: EPCs are very important for defining HEP as they have a negative impact on human characteristics $[26 ; 27 ; 13 ; 19]$. Using a small number of EPCs is obviously present in the scenarios which produce precise results.

Expert Impact Assessment: Proportion of Affect (POA) is the most difficult step for experts having in mind that selection of general categories and EPCs is a very complex process. Experts are reluctant to use the scenarios with large number of EPCs as these scenarios give confusing and poor results. For each EPCs expert, the assessment of 
probability on scale from 0 to 1 is determined, and that assessed overall HEART impact is assessed using the following expression:

$$
E=((M E-1) \cdot E A)+1
$$

Where: ME - maximum HEART effect, EA - expert assessment of EPCs on analyzed system (assessed POA), E - assessed overall HEART effect.

Based on the classification of tasks and assessed effect for each EPCs total probability of human error is determined.

$$
H E P=N H U \cdot E_{1} \cdot E_{2} \cdot e t c .
$$

Where: NHU - Nominal Human Unreliability for generic task; E1, E2... - Assessed overall HEART effect for EPCs.

Error Reduction: Reduction is done based on the nominal probabilities assessment and ranging, with necessary formation of specific Error Reduction Mechanisms (ERMs).

Documentation: Documentation is very important if large number of HEART calculations is done. It is important that expert's assumptions are adequately recorded, especially those that refer to the expert impact assessment.

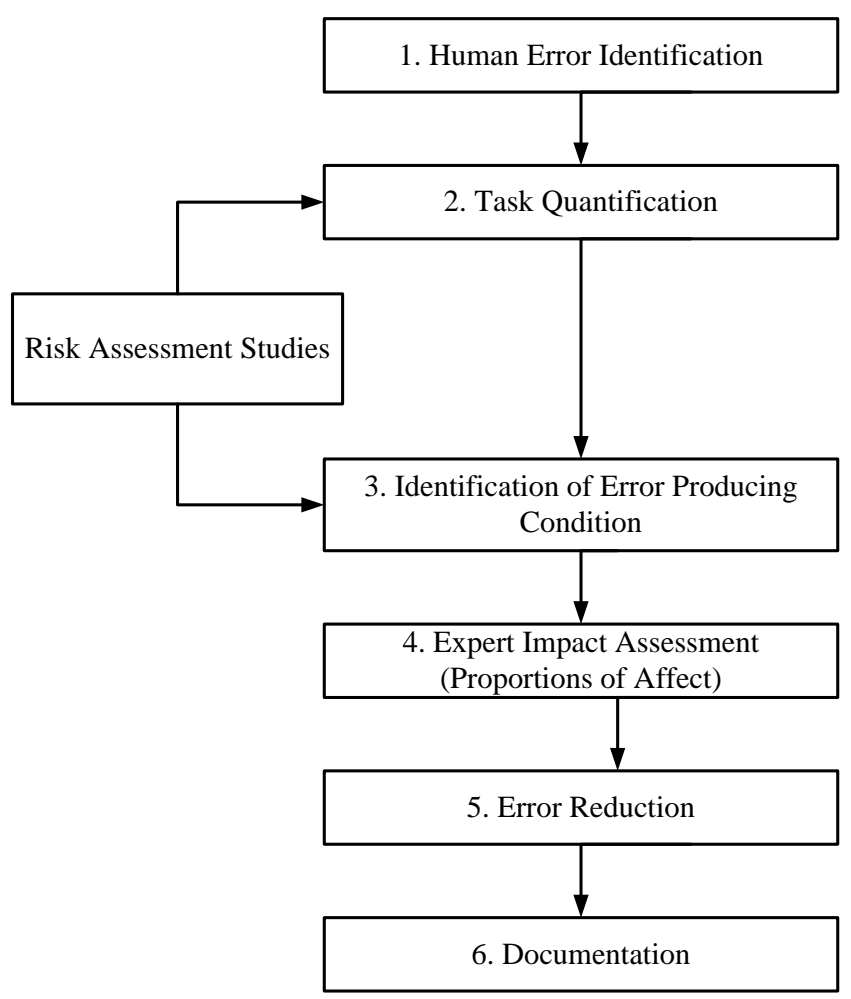

Fig. 1 HEART procedural steps 


\section{RESULTS AND DISCUSSION}

The HEART was used for HRA in the Electric Power Company of Serbia (EPCS). The research comprised the analysis of 1074 workplaces with a total of 3997 employees. The expert team, experienced in the field of HRA, had appropriate knowledge of all sectors, activities, and procedures within EPCS. Most of them were with over 20 years of professional experience and some were the direct executives of the Risk Assessment Project that was implemented in EPCS. Previous consideration of accidents in the EPCS indicated that the largest number of accidents occurred at $10 / 0.4-\mathrm{kV}$ steel lattice towers. Therefore, the expert team has focused their attention on this object in order to identify human errors. For the purpose of this study, a database on work-related injuries, accidents and critical interventions that occurred over a ten-year period has been developed.

In the following text, the results that refer to the HRA case study related to a repair intervention on a 10/0.4-kV steel lattice tower "Maričiće", Kuršumlija (jurisdiction of EPCS, ED "Jugoistok", Nis, Serbia) are presented. Detailed expert analysis based on the use of the HEART has resulted in identification of 10 typical human errors. These are the following:

1. Improper and imprecise issue of a work order;

2. Lack of job authorization;

3. Failure to implement the fundamental principles of job organization;

4. Inadequate cooperation between operators;

5. Incomplete implementation of safety measures on the job site;

6. Breach of field operation protocol;

7. Erroneous routine operations, which require meticulous attention;

8. Communication error;

9. Failure to use prescribed tools, and

10. Failure to use the prescribed personal safety equipment.

For researched case, the following tasks are quantified:

$\mathrm{G}$ - Simple task, performed quickly or with limited attention, with proposed limit for nominal human unreliability $(5-95 \%)$ of 0.09 .

D - General, routine, very practical, quick task, requiring relatively low skill level, with proposed limit for nominal human unreliability (5-95\%) of 0.02 .

E - Totally familiar, properly designed and accurate, routine task, performed by a highly motivated, properly trained and experienced operators that are aware of possible implications or failures, with sufficient time to correct the potential error, with proposed limit for nominal human unreliability (5-95\%) of 0.0004 .

Error producing conditions are based on the analysis of human performance literature. For the researched case, following EPCs (Table 1) which have a negative impact on the human characteristics have been selected. 
Table 1 EPCs for case study

\begin{tabular}{|c|c|c|}
\hline $\mathrm{Nm}$ & $\mathrm{EPC}_{\mathrm{S}}$ & $\begin{array}{l}\text { Maximum HEART Effect } \\
(\mathrm{ME})\end{array}$ \\
\hline 1. & Ignoring easily accessible information. & X9 \\
\hline & $\begin{array}{l}\text { Inadequate transfer of spatial and functional information to the } \\
\text { operator. }\end{array}$ & X 8 \\
\hline & A mismatch between perceived and real risk. & X 4 \\
\hline 4. & Inadequate action after performed control. & $\mathrm{X} 4$ \\
\hline & $\begin{array}{l}\text { An impoverished quality of information conveyed by } \\
\text { procedures and person-to-person interaction. }\end{array}$ & X 3 \\
\hline & Insufficient checking of output information. & X 3 \\
\hline & $\begin{array}{l}\text { Training. Poor quality of information in procedures and } \\
\text { inadequate training are causing poor interaction between } \\
\text { operators. }\end{array}$ & X 3 \\
\hline & $\begin{array}{l}\text { Inexperience: Personal approach to assessing of hazards can be } \\
\text { adequate only for experienced operators, while others must use } \\
\text { standardized procedures. }\end{array}$ & X 3 \\
\hline & Inadequate education of operators in relation to the given tasks. & $X 2$ \\
\hline & Incentive for using alternative procedures. & $\mathrm{X} 2$ \\
\hline 11. & Unclear allocation of functions and responsibilities. & X 1.6 \\
\hline & $\begin{array}{l}\text { Low workforce morale: Management must constantly support } \\
\text { the activities of operators by improving safety condition, } \\
\text { through various additional explanations and instructions. }\end{array}$ & X 1.2 \\
\hline
\end{tabular}

On account the quantified task and assessed overall effect of EPCs we determined the human errors probabilities for each task (Table 2, 3, 4).

Based on everything mentioned above we can conclude that the use of HEART method provides a group assessment of human error probabilities for break downed tasks and activities, whereas EPCs are considered during the assessment (i.e. conditions that have a significant impact on occurrence of human error). Also, based on the quantified human error with application of HEART method, and taking into account the calculated values of EPCs, following conclusions can be made:

- HEP value of $5.2 \cdot 10^{-3}$ indicates that following human errors are most probable: improper and imprecise issue of a work orders and lack of job authorization. Ignoring easily accessible information is the main condition (63.46\%) contributing to improper execution of initial activities in the analyzed case, followed by incentive for using alternative procedures $(14.42 \%)$, unclear allocation of functions and responsibilities $(11.92 \%)$ and low workforce morale (10.20\%) (Table 2).

- HEP value of $7.8 \cdot 10^{-1}$ indicates that following human errors are most probable: failure to implement the fundamental principles of job organization, inadequate cooperation between the operators, and incomplete implementation of safety measures on the job site and breach of field operation protocol. In this case, inadequate action after performed control $(35.21 \%)$ is the main factor contributing to the increased probability of human error which requires a lot of attention in order to reduce errors (Table 3). Other factors are an impoverished quality of information conveyed by procedures and person-to-person interaction $(25.35 \%)$, insufficient checking or testing of output information (22.54\%), and training (16.9\%). 
- HEP value of $8.7 \cdot 10^{-1}$ indicates that following human errors are most probable: erroneous routine operations, which require meticulous attention, communication error, failure to use prescribed tools and failure to use the prescribed personal safety equipment. In this case, inadequate transfer of spatial and functional information to the operator (34.24\%) is the main factor contributing to the increased probability of human error, followed by a mismatch between perceived and real risk (30.63\%), inexperience $(23.42 \%)$ and inadequate education of operators in relation to the given tasks $(11.71 \%)$ (Table 4). Therefore, it is important to start timely development of preventive strategies for assessment, prediction and reduction of human errors, and in this way to reduce the consequences and serious financial losses.

Table 2 Quantification of HEP for task E

\begin{tabular}{|c|c|c|c|c|}
\hline EPCs & $\mathrm{ME}$ & EA & $\mathrm{E}$ & $\begin{array}{l}\text { Contribution made } \\
\text { to unreliability } \\
\text { modification [\%] }\end{array}$ \\
\hline \multicolumn{5}{|c|}{ NHU for generic task E - $\mathbf{0 . 0 0 0 4}$} \\
\hline Ignoring easily accessible information. & X 9 & 0.7 & 6.60 & 63.46 \\
\hline Incentive for using alternative procedures. & X 2 & 0.5 & 1.50 & 14.42 \\
\hline $\begin{array}{l}\text { Unclear allocation of functions and } \\
\text { responsibilities. }\end{array}$ & X 1.6 & 0.4 & 1.24 & 11.92 \\
\hline $\begin{array}{l}\text { Low workforce morale: Management must } \\
\text { constantly support the activities of operators by } \\
\text { improving safety condition through various } \\
\text { additional explanations and instructions. }\end{array}$ & $\mathrm{X} 1.2$ & 0.3 & 1.06 & 10.20 \\
\hline HEP & \multicolumn{3}{|c|}{$5.2 \cdot 10^{-3}$} & 100 \\
\hline
\end{tabular}

Table 3 Quantification of HEP for task G

\begin{tabular}{|c|c|c|c|c|}
\hline EPCs & $\mathrm{ME}$ & EA & $\mathrm{E}$ & $\begin{array}{l}\text { Contribution made } \\
\text { to unreliability } \\
\text { modification [\%] }\end{array}$ \\
\hline \multicolumn{5}{|c|}{ NHU for generic task $\mathrm{G}-\mathbf{0 . 0 9}$} \\
\hline Inadequate action after performed control. & $\mathrm{X} 4$ & 0.5 & 2.50 & 35.21 \\
\hline $\begin{array}{l}\text { An impoverished quality of information } \\
\text { conveyed by procedures and person-to-person } \\
\text { interaction. }\end{array}$ & X 3 & 0.4 & 1.80 & 25.35 \\
\hline Insufficient checking of output information. & X 3 & 0.3 & 1.60 & 22.54 \\
\hline $\begin{array}{l}\text { Training. Poor quality of information in } \\
\text { procedures and inadequate training are causing } \\
\text { poor interaction between operators. }\end{array}$ & X 3 & 0.1 & 1.20 & 16.90 \\
\hline HEP & \multicolumn{3}{|c|}{$7.8 \cdot 10^{-1}$} & 100 \\
\hline
\end{tabular}


Table 4 Quantification of HEP for task D

\begin{tabular}{|c|c|c|c|c|}
\hline EPCs & ME & EA & $\mathrm{E}$ & $\begin{array}{c}\text { Contribution made } \\
\text { to unreliability } \\
\text { modification [\%] }\end{array}$ \\
\hline \multicolumn{5}{|c|}{ NHU for generic task D $-\mathbf{0 . 0 2}$} \\
\hline $\begin{array}{l}\text { Inadequate transfer of spatial and functional } \\
\text { information to the operator. }\end{array}$ & $\mathrm{X} 8$ & 0.4 & 3.80 & 34.24 \\
\hline A mismatch between perceived and real risk. & $\mathrm{X} 4$ & 0.8 & 3.40 & 30.63 \\
\hline $\begin{array}{l}\text { Inexperience: Personal approach to assessing } \\
\text { of hazards can be adequate only for } \\
\text { experienced operators, while others must use } \\
\text { standardized procedures. }\end{array}$ & $\mathrm{X} 3$ & 0.8 & 2.60 & 23.42 \\
\hline $\begin{array}{l}\text { Inadequate education of operators in relation to } \\
\text { the given tasks. }\end{array}$ & $\mathrm{X} 2$ & 0.3 & 1.30 & 11.71 \\
\hline HEP & & $8.7 \cdot 10^{-1}$ & & 100 \\
\hline
\end{tabular}

In reference to the results of the conducted research, it has been noticed that the human error with the highest probability is the failure to use the prescribed tools. The most common cause of this human error is related to a PSFs and EPCs. There are indicators related to the operator and the working environment, which influence operations, positively or negatively. In this regard, for the most of operators over 50 years of age, experience appeared as the significant PSFs. A common but negative effect in the EPCS is that the older operators consider themselves sufficiently experienced and confident when performing their tasks [23]. In this case, they are not highly motivated to use tools and equipment for personal safety (which is also the frequent cause of accidents in other companies that distribute electric energy). Additionally, such workers set a bad example for the younger ones who often accept this kind of risky behavior. In such situation, strict application of the internal and external regulations, training and education, can be recommended as measures for reducing this source of human error [23].

\section{CONCLUSION}

In EPCS, in addition to demands for continuous, stable, and electric energy supply of standard quality, it is essential to implement the appropriate working control and management. The higher and lower management of the company, as well as workers on the terrain, were appropriately informed about the findings of this research. Results obtained in this case study, according to the positive feedback from the EPCS, have contributed to the following: increased operators' reliability; reduced human error occurrence and increased awareness on significance of occupational safety and health measures application; prevented occupational injuries and fatalities; increase in productivity, and decrease in lost work hours and expenses; and improvement of environmental protection (standards) practice, through reduction of damage in electric power plants, reduction of environmental pollution, and substantial economic loss.

Proceeding from the research results, beside the specific conclusion for the analyzed case (HEART was used for HRA in the EPCS), we came to the following conclusions: 
- Quantification of human errors and determination of EPCs point out that reduction and prevention of error repetition is necessary.

- Assessment did not require more than one expert.

- During the assessment, EPCs were considered without possible interactions between different EPCs.

- Many EPCs can be assessed for existing facilities, but cannot be used for forecasting the state of a new i.e. proposed or developing facility.

- EPCs are based on analysis of human performance commonly found in literature so different experts can use them in their own way.

- Practical experience showed that HEART could adequately predict HEP while offering a series of practical error-reduction strategies that can be used for reducing the impact of error on the system or for preventing them.

- HEART is very applicable in all industries.

\section{REFERENCES}

1. Bell, J., Williams J.C. (2016). Consolidation of the HEART Human Reliability Assessment Principles. Proceedings from: IChemE Symposium Series No. 161. Hazards 26. UK, Cleveland: ABB Engineering Services.

2. Boring, R.L. (2006). Modeling human reliability analysis using MIDAS. International Workshop on Future Control Station Designs and Human Performance Issues in Nuclear Power Plants. (Retrieved from http://citeseerx.ist.psu.edu/viewdoc/download?doi=10.1.1.627.5951\&rep=rep1\&type=pdf).

3. Castiglia, F., Giardina, M., Tomarchio, E. (2015). THERP and HEART integrated methodology for human error assessment. Radiation Physics and Chemistry, 116, 262-266.

4. Castiglia, F., Giardina, M., Tomarchio, E., (2010). Risk analysis using fuzzy set theory of accidental exposure of medical staff during breach therapy procedures. Journal of Radiological Protection, 30, 49-62.

5. Chadwick, L., Fallon, E.F. (2012). Human reliability assessment of a critical nursing task in a radiotherapy treatment process. Applied Ergonomics, 43 (1), 89-97.

6. Drews, F.A., Musters, A., Markham, B., Samore, M.H. (2007). Error Producing Conditions in the Intensive Care Unit. Proceedings of the 51st Annual Meeting of the Human Factors and Ergonomics Society. Baltimore: MD.

7. Dsouza N., Lu L. (2017). A Literature Review on Human Reliability Analysis Techniques Applied for Probabilistic Risk Assessment in the Nuclear Industry. In: Cetiner S., Fechtelkotter P., Legatt M. (Eds.) Advances in Human Factors in Energy: Oil, Gas, Nuclear and Electric Power Industries (Part of the Advances in Intelligent Systems and Computing, Book series (AISC, volume 495)), 41-54.

8. Gibson, W., Dennis, C., Thompson, Mills, A., Kirwan, B. (2012). Tailoring the HEART technique for application in the rail industry. Advances in Safety, Reliability and Risk Management - Bérenguer, Grall \& Guedes Soares (Eds.). London: Taylor \& Francis Group.

9. Griffith, C.D., Mahadevan, S. (2011). Inclusion of fatigue effects in human reliability analysis. Reliability Engineering \& System Safety, 96 (11), 1437-1447.

10. Grozdanovic, M., Stojiljkovic, E. (2013). Risk Assessment Methods. Nis: University of Nis, Faculty of Occupational Safety, (in Serbian).

11. Hollnagel, E. (1998). Cognitive Reliability and Error Analysis Method - CREAM. UK: Oxford: Elsevier Science.

12. Iannone, R., Miranda, S., Riemma S. (2004). Proposta di un modello simulativo per la deter minazione automatica delle pause di lavoro in attività manifatturiere a prevalente contenuto manuale. Treviso - Italy ANIMP Servizi Srl Pag. 46-60.

13. Kirwan, B. (1994). A Guide to Practical Human Reliability Assessment. UK, London: Taylor \& Francis.

14. Kirwan, B. (1996). The validation of three human reliability quantification techniques - THERP, HEART and JHEDI: Part 1 - Technique descriptions and validation issues. Applied Ergonomics, 27 (6), 359-373.

15. Kirwan, B. (1997a). The validation of three human reliability quantification techniques - THERP, HEART and JHEDI - Part 2 - Results of validation exercise. Applied Ergonomics, 28 (1), 17-25. 
16. Kirwan, B. (1997b). The validation of three human reliability quantification techniques - THERP, HEART and JHEDI - Part 3 - Practical aspects of the usage of the techniques. Applied Ergonomics, 28 (1), 27-39.

17. Mosleh, A., Chang, Y.H. (2004). Model-based human reliability analysis: prospects and requirements. Reliability Engineering and System Safety, 83 (2), 241-253.

18. Noroozia, A., Khan, F., MacKinnon, St., Amyotte, P., Deacon, T. (2014). Determination of human error probabilities in maintenance procedures of a pump. Process Safety \& Environmental Protection (Transactions of the Institution of Chemical Engineers Part B. (Mar 2014)), 92 (2), 131-141.

19. Stojiljkovic, E. (2011). Methodological Framework for Human Error Assessment. Ph.D. Thesis. Nis: University of Nis, Faculty of Occupational Safety, (in Serbian).

20. Stojiljković, E. (2013). The Application of an Event Tree for Human Error Analysis in the Electric Power Company in Serbia. Facta Universitatis, Series: Working and Living Environmental Protection, $10(2), 135-142$.

21. Stojiljkovic, E. (2017). Knowledge management for the purpose of human error reduction. Proceedings from M\&S 2017 (CD1): 12th International Conference Management and Safety (Neum and Mostar, Bosnia and Herzegovina, 9-10. June 2017.), Čakovec, Croatia: The European Society of Safety Engineers, pp. 1-8 (Invited lecture paper).

22. Stojiljkovic, E., Glisovic, S., Golubovic, T. (2014). Risk Assessment of Industrial and Environmental Monitoring Systems - The Significance of Human Reliability Analysis. Facta Universitatis, Series: Working and Living Environmental Protection, 11 (2), 145 - 152.

23. Stojiljkovic, E., Glisovic, S., Grozdanovic, M. (2015). The Role of Human Error Analysis in Occupational and Environmental Risk Assessment: A Serbian Experience. Human and Ecological Risk Assessment: An International Journal, 21 (4), 1081-1093.

24. Stojiljkovic, E., Janackovic, G., Grozdanovic, M., Savic, S., \& Zunjic, S. (2016). Development and Application of a Decision Support System for Human Reliability Assessment - A Case Study of an Electric Power Company. Quality and Reliability Engineering International, 32 (4), 1581-1590.

25. Swain A. D. (1989). Comparative evaluation methods for human reliability analysis. Report No. GRS71. Köln, Germany: Gessellschaft für Reaktorsicherheit.

26. Williams, J.C. (1986). HEART - a proposed method for assessing and reducing human error. Proceedings from $9^{\text {th }}$ Advances in Reliability Technology Symposium. England, West Yorkshire: University of Bradford.

27. Williams, J.C. (2015). Heart—a Proposed Method for Achieving High Reliability in Process Operation by Means of Human Factors Engineering Technology. Safety and Reliability, 35 (3), 5-25.

\section{PRIMENA HEART METODE ZA PROCENU LJUDSKE POUZDANOSTI - SRPSKO ISKUSTVO}

U kompleksnim industrijskim sistemima ljudska greška je često navedena kao uzrok ili glavni faktor koji dovodi do akcidenata i katastrofa. Potreba za poboljšanim metodologijama za procenu ljudske pouzdanosti, koje se primenjuju u probabilističkoj proceni bezbednosti, još od ranih 1990-tih motivisala je brojna istraživanja. Glavni cilj ovag rada je da prikaže praktičnu primenu "Tehnike za procenu i redukciju ljudske greške" u proceni ljudske pouzdanosti u preduzeću "Elektroprivreda Srbije”. Korisnost ovog alata, za ovu namenu, dokazana je u studiji slučaja u kojoj je izvršena analiza akcidenta do koga je došlo prilikom intervencije na čelično-rešetkastoj TS 10/0,4kV „Maričiće“, Kuršumlija, ED „Jugoistok“, Niš. Za potrebe ove studije kreirana je baza podataka o povredama na radu, akcidentima i kritičnim intervencijama u poslednjih 10 godina. Istraživanje je obuhvatilo analizu 1074 radna mesta sa ukupno 3997 zaposlenih. Studija slučaja koja je sprovedena u Elektroprivredi Srbije potvrdila je da se "Tehnika za procenu i redukciju ljudske greške" zasniva na poznavanju aktivnosti operatora $i$ da za procenu "uslova za nastanak greške", koristi stručno mišljenje eksperata. Tehnika za procenu i redukciju ljudske greške može da se koristi u različitim industrijskim sistemima kao alat za procenu rizika, analizu akcidenata i projektovanje. To je relativno brz, lako razumljiv i jednostavan alat za procenu verovatnoće ljudske greške.

Ključne reči: Procena ljudske pouzdanosti, Ljudska greška, Metod procene i redukcije ljudske greške, Uslovi za nastanak greške. 